\title{
Studies in Geochemical Classification of Granitic Rocks from Zungeru, North-western Nigeria
}

\author{
Kankara, I. A. and Omoti Abubakar
}

\begin{abstract}
Granitic rocks are possibly the most common igneous rocks known. They belong to a class of igneous rocks that are formed from molten magma. They are classified by the minerals they contain. The rocks vary in composition from syenite to granodiorite to tonalite to true granites. With the use of X Ray fluorescence the major and trace elements are determined, and classified based on the following schemes: This geochemical classification of granitic rocks is based upon three (3) variables: $\mathrm{FeO} /(\mathrm{FeO}+\mathrm{MgO})=\mathrm{Fe}$ - number [ or $\mathrm{FeO}$ total $\left.\left./ \mathrm{FeO}_{\text {total }}+\mathrm{MgO}\right)=\mathrm{Fe}^{*}\right]$, the modified Alkali -Lime Index (MALI) $\left(\mathrm{Na}_{2} \mathrm{O}+\mathrm{K}_{2} \mathrm{O}-\mathrm{CaO}\right)$ and the Aluminium Saturation Index (ASI) $\quad[\mathrm{Al} /(\mathrm{Ca}-1.67 \mathrm{P}+\mathrm{Na}+\mathrm{K})]$. The $\mathrm{Fe}$ number (or $\mathrm{Fe}^{*}$ ) distinguishes ferroan granitoids, which manifest strong iron enrichment from magnesium granitoids, which do not. The ferroan and magnesium granitoids can further be classified into Alkalic, Alkali-Calcic, Calc-Alkalic and Calcic on the basis of the MALI and sub-divided on the basis of the ASI into Peraluminous, metaluminous or peralkaline.
\end{abstract}

Keywords-Geochemical Character, granitic rocks, Zungeru, Northwest Nigeria.

\section{INTRODUCTION}

Granitic magma is associated with several tectonic stages during evolution, and their structures, texture and mineralogical composition can be of benefitial and have environmental impact [1,2] The Older Granites of Nigeria include a wide spectrum of rocks varying in composition from tonalite through granodiorite to granite, syenite and charnockite rocks [2] The graitoid have been emplaced into both the migmatite-gneiss complex and the schist belts and they occur in all parts of Nigeria [3] Recent works in different parts of Nigerian Basement complex has shown that the older granites are high level intrusions emplaced by diapiric processes [3]

The generally north-south linear aggregation of many large batholiths of the basement suggests that they may be related to deep-seated pre-existing plutonic episode controlled by major deep mantle structure [4] The intense regional deformation which accompanied and preceded the emplacement of the older granite resulted in the pronounced and wide spread of N-S trend. The granites were termed the older granites in Nigeria, and have been dated severally at 500-750 Ma [4, 5]

Minna is situated in the central part of the Nigerian basement complex and is surrounded by rugged terrain of granitic rocks. The area comprises of meta-igneous and metasedimentary rocks which have undergone polyphase deformation and metamorphism.

Dr. Aliyu Ibrahim Kankara, Lecturer I, Federal University DutsinMa, Kastina State, Nigeria
These rocks have been intruded by granitic rocks of PanAfrican age. There is need to examine the origin, attributes and benefits of these rocks in the area.

\section{SCOPE AND OBJECTIVES}

The scope of the work is to carry out a classification of the rocks of the study area using major and trace elements. The work involves geologic mapping and study of samples was carried out both in the field and in the laboratory.

The main objective of the study is to carry out a geochemical classification of granitic rocks around the study area. This work therefore has the following specific objectives:

1. To carry out field work of the study area.

2. To carry out geochemical analyses for major and trace elements using the X-Ray Flourescence (XRF) method. The results of the analyses will be used to classify the granites geochemically.

\section{LOCATION AND EXTENT}

The area of study is around Maikunkele and falls between latitude $9^{\circ} 39^{\prime} \mathrm{N}$ and longitude $9^{\circ} 43 \mathrm{~N} 6^{\circ} 26^{\prime} \mathrm{E}$ and $6^{\circ} 30^{\prime} \mathrm{E}$ on Zungeru Sheet $163 \mathrm{SE}$ and covers an area of 14 square kilometres (see figure 1). The area is accessible through a feeder road that leads from Minna to Zungeru and several footpaths which link most of the settlements.

\section{RESUlTS}

\section{A. Materials and Methods}

The work is divided into field and laboratory phases. This involves geologic mapping (see figure 2) and collections of samples from the fields.

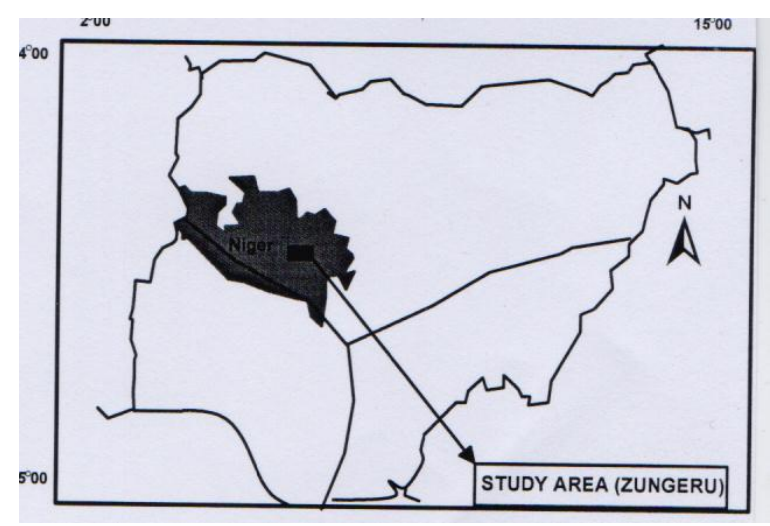

Fig.1: Map of Nigeria showing the study area 


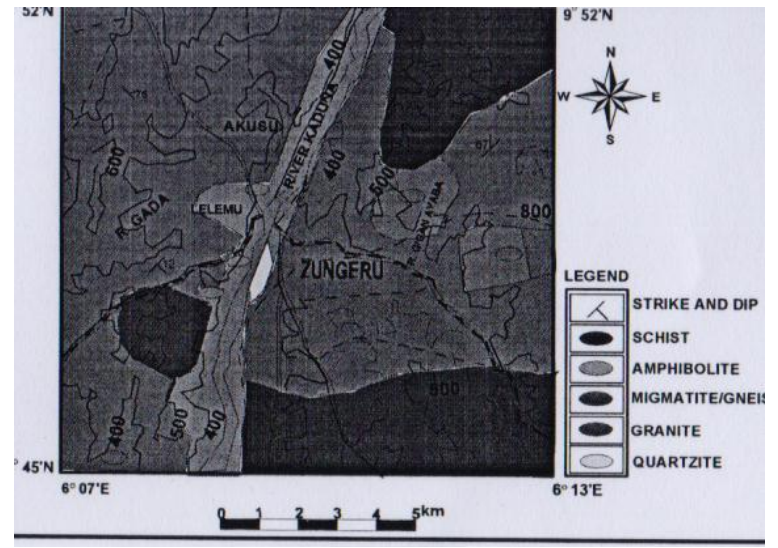

Fig. 2: Geological map of the study area.

The materials needed for the fieldwork include a Global Positioning System (GPS), device, hammer, compass clinometers, marker, hand lens and sample bags. The second phase is the laboratory phase, involving analysis of the samples collected from the field for major and trace elements, using X-Ray Fluorescence method.

\section{B. Geochemical Classification and Schemes}

Despite the fact that granites are the most abundant rocks on the continental crust yet there is no particular classification scheme has achieved a wide spread use. This is due to the fact that the minerals which make up the granite; quartz, feldspar and ferromagnesian minerals can be formed from a number of processes. Granitic rocks could be formed from any hypersthene-normative melt, partial melting from any rock type, also from crustal- derived melt and mantle-melt and sometimes both [6] Due to this complexity petrologists relied on chemical classification to distinguish these various granitoid groups, and approximately 20 different classification schemes have evolved over the past 30 years. These schemes are either genetic or tectonic in nature [7]

The International Union of Geo-Sciences (IUGS) adopted a classification scheme which focuses on the differences in abundances and compositions of feldspar. This scheme can be applied easily in the field with ease and is inexpensive and non genetic, but the disadvantage is that it ignores compositional variations apart from those that affect the feldspar abundances. Thus, felsic and mafic granitoids may plot on the same field but have significantly different chemical compositions. This prompted so many petrologists to look into other ways to further classify the granitoids.

Chappeil and White (1974) introduced a classification scheme after extensive work in the Lachlan fold belt of Eastern Australia. In this, two granitoid groups were recognized; the I-type which is metallauminous to weekly peraluminous, relatively sodic with a wide range of silica content (56-77 wt $\left.\% \quad \mathrm{SiO}_{2}\right)$ and the $\mathrm{S}$-type is strong peralluminous, relatively potassic and restricted to higher silica content (64-77wt\% o) The S-type and I-type were said to have originated from a metasediment and a meta igneous source respectively. The scheme is based upon the fact that one can easily distinguish the granitoid precursor. However, similar granitic compositions can be produced by partial melting of different sources [4]
In 1978, Loiselle and Wones introduced yet another term. This they called the A-type granites. They recognized a distinctive type of granite that was rich in potassium $(\mathrm{K})$, had a high $\mathrm{FeO} /(\mathrm{FeO}+\mathrm{MgO})$ ratio and had a high amount of Zircon $(\mathrm{Zr})$. They were found to be rarely deformed and intruded long after the youngest deformation, they were called Anorogenic granites. Loisselle and Wones called these A-type granites because of their Alkalinity, Anhydrous character, and presumed Anorogenic tectonic setting.

The M-type and the C-type granites were proposed by White in 1979 and Kilpatrick and Ellis in 1992 respectively. The M-type granites are thought to arise from the mantle, specifically in island arc settings $[6,8]$. The C-type granites were thought to be derived from charnockitic magma and contain orthopyroxene, pigeonite and fayalite.

The M-type proposed by White was criticized based on the fact that granitic rocks of this kind could also be formed from partial melting of juvenile crust which was similar to the Itype. Another concern was that magma of mantle origin had its composition determined by other factors and not majorly its origin as rocks such as tonalite [9] and fayalite granite [7] and per alkaline granite $[3,5]$ is thought to be derived from the mantle also.

The alphabetic classification works on the assumptions that granitoids are formed from a single source and this can be interpreted from the chemical composition of the rocks but in reality granites arises from different sources. They are mixtures of mantle and crustal melts with or without metasedimentary components [10]

A classification scheme was also proposed by Babarin (1999) using the mineralogy of the rocks and relating it to the Aluminium saturation of the rocks. Different tectonic environment were linked to the 6 granitoid types. Babarin was able to relate composition to mineralogy but narrowed the wide range of granitic composition types into 6 rock types.

There are also other classification schemes (non alphabetic) which could he used to geochemically classify granitic rocks. They include the $\mathrm{Fe}$-number or $\mathrm{Fe}^{*}$. The iron number is the ratio of the $\mathrm{FeO} /(\mathrm{FeO}+\mathrm{MgO})$ and its variation with the silica content. This gives a History of magmatic differentiation. Some rock suites undergo iron enrichment with their silica content remaining low and vice versa (Nockolds \& Allen 1956), these trends are called tholeitic and calc-alkaline rocks. Miyashiro (1970) was able to distinguish these suites using a plot of $\mathrm{FeO} / \mathrm{FeO}+\mathrm{MgO}$ ) against silica.

There is also a Modified Alkali-lime index (MALI) which was proposed by Peacock in 1931. He was able to group suites into four categories based on their Alkali-lime index (ALI) which is simply the silica content at which $\mathrm{Na}_{2} \mathrm{O}+\mathrm{K}_{2} \mathrm{O}$ in a particular suite equals $\mathrm{CaO}$. Where he found suites to have a value $>61$, he called them Calcic. In suites ranging from 56-61, he called them Calc-Alkalic. Ranges from 51-56 and those less than 51(<51) he called them Alkali-Calcic and Akalic respectively. The Modified Alkali-lime index (MALI) is defined as $\mathrm{Na}_{2} \mathrm{O}+\mathrm{K}_{2} \mathrm{O}-\mathrm{CaO}$ and it reduces the three variables that is $\mathrm{SiO}_{2}, \mathrm{CaO}$ and $\mathrm{Na}_{2} \mathrm{O}+\mathrm{K}_{2} \mathrm{O}$ to two. When the MALI is zero the silica content of that suite is equal to the ALl of peacock.

The Aluminium Saturation index is another useful scheme for classifying granitic rocks. In 1934 Shand proposes a 
scheme using the Aluminium contained in a rock. This he called the Aluminium saturation index. It is the molecular ratio of $\mathrm{Al} /(\mathrm{Ca}-1.67 \mathrm{P}+\mathrm{Na}+\mathrm{K})$. If the $\mathrm{ASI}$ is greater than one, the rock is termed peralluminous. If the ASI is less than 1 and molecular $\mathrm{Na}+\mathrm{K}$ is less than Molecular Aluminium the rock is termed metalluminous. The rock is peralkaline if ASI is less than 1 and the molecular $\mathrm{Na}+\mathrm{K}$ is greater than Aluminium. This present study uses the Chappell and White's system of classification where the samples collected were subjected to chemical analyses to show the various percentages of each major and minor (trace) elements (see Appendixes 1 and 2) and from there their source magmas could be identified.

\section{Geotectonic Classification}

Granitic rocks could be classified using trace elements. This was demonstrated in the analyses conducted by Julian A. Pearce in 1984. About 600 analyses were used to distinguish 4 major tectonic environments:

ocean ridge granites,

$\sim$ volcanic arc granites,

$\sim$ within plate granites and

$\sim$ collision granites.

The best discriminators were plots of $\mathrm{Nb}$ vs $\mathrm{Y}$, Ta vs $\mathrm{Y}$, $\mathrm{Rb}$ vs $(\mathrm{Yb}+\mathrm{Nb}), \mathrm{Rb}$ vs $\mathrm{Yb}+\mathrm{Ta})$. The scheme was widely accepted and is often employed as a means of determining the tectonic environments of granitoids whose tectonic settings have been lost. The result from the analyses will be used to classify the rocks geochemically. Plots (variation diagrams) can later be drawn and the rocks will be grouped into peralluminous, metaluminous and peralkaline using the Aluminium saturation index. They will also be grouped into calcic, calc-alkalic, alkali-calcic and alkalic using the Alkali lime index. The iron number will be used to categorize the rocks into ferroan and magnesian suites.

\section{D. a. Field Observation}

The rock types encountered in the mapped area include migmatite-gneisses, schists, amphibolites, quartzites and minor granitic intrusions as shown on the geological map (Figure 2; see plate III). The gneisses occupy most of the study area and include the granite gneiss and the banded (grey) gneiss, Both gneisses have intruded the schist and themselves have in turn been intruded by some granitic intrusions. The gneisses occur as hilly, massive and low lying outcrops, where they form contact with the schist (see plates I, II and IV) The schist and amphibolites occupy the central part of the study area and are boarded by approximately N-S trending units of the migmatites-gneiss complex.

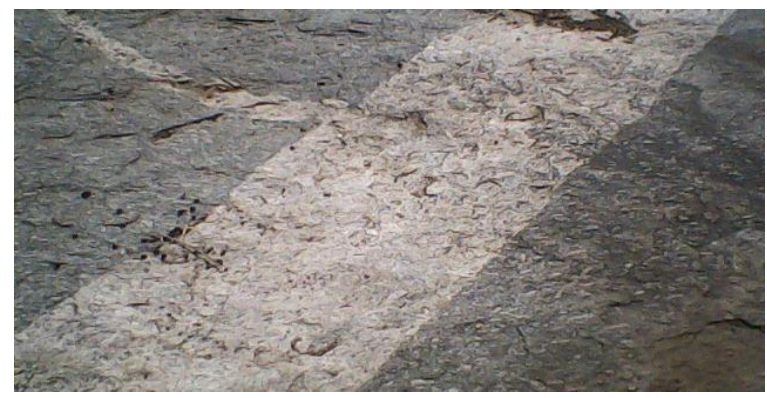

Plate 1: A $30 \mathrm{~cm}$ wide Pegmatite in a granite,Zungeru

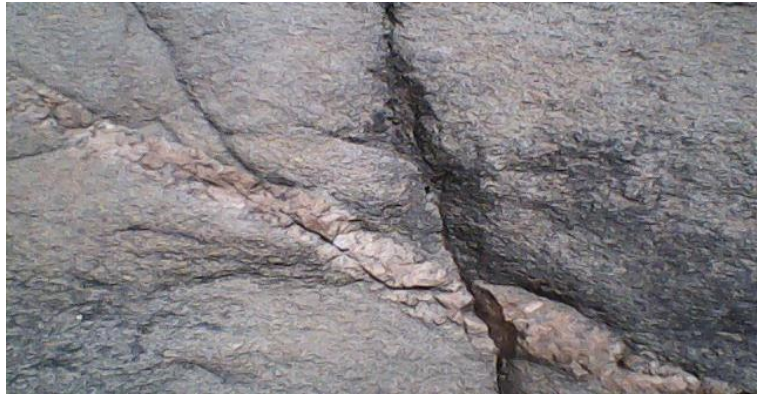

Plate II: Joint along a Pegmatite dyke at near Maikunkele.

\section{D. b. Laboratory Observation}

\section{1. Thin Section}

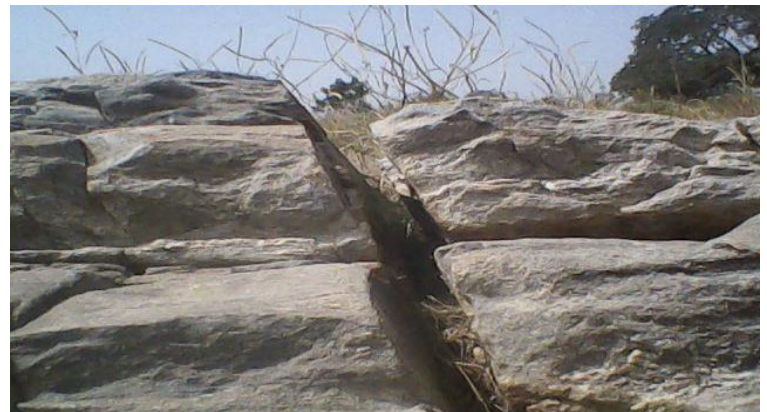

Plate III: Major fault in a granite gneiss, close to Zungeru.

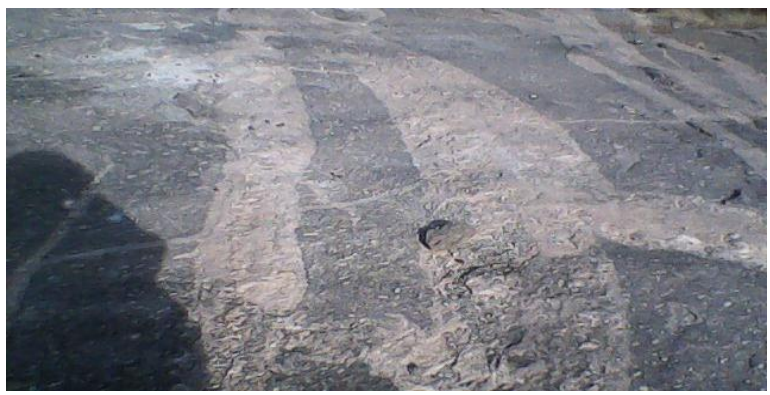

Plate IV: Multiple Pegmatites (Pegmatite Pods) along MinnaZungeru Road.

\section{E. Discrimination Diagram}

Discrimination diagrams seldom gave a better understanding of an environment. They can be used to suggest an affiliation, but should never be used as a proof. This is all the more important the further back in time we go and the further away we move from the control of samples used in the construction of the diagrams. For example, using a discrimination diagram constructed from modern volcanic rocks to postulate an Archean volcanic setting is likely to produce equivocal results [11]. Furthermore, discrimination diagrams were never intended to be used for single samples, but rather with a suite of samples. This simple precaution will eliminate the occasional spurious results and highlight datasets from mixed or multiple environments. Clearly, diagrams produced in the 1970's are more fully tested than those published recently and so in general they obtain the poorer reviews. These are sometimes justified but often reflect an increased level of understanding of both tectonic 
environments and geochemical processes since the publication of the diagram.

\section{CONCLUSION}

After the chemical analyses are carried out and the rocks classified geochemically into various fields, using variation diagrams the rocks will be grouped into granites, tonalites, syenites, granodiorites, monzonites etc.

\section{REFERENCES}

[1] Alabi, A. (2011) Geology and Environmental Impact Assessment and benefits of granitic rocks of Minna Area, Northwestern Nigeria.

[2] Dada, S. (2006) Proterozoic evolution of Nigeria. In: Oshi O (ed) The Basement complex of Nigeria and its mineral resources (A tribute to Prof. M. O. A. Rahman). Akin Jinad \& Co. Ibadan. 29-44.

[3] Ajibade, A. C. Fitches, W. R. and Wright, J. B. (1979). The Zungeru Mylonites, Nigeria: recognition of a major Tectonic Belt. Revise de Geologie and Physics 21:359-3639.

[4] Chapell, B. W., \& White, A. (1974) Two Contrasting Granite Types. Pacific Geology, 8. 173-174.

[5] Woakes, M., Rahaman, M.A. \& Ajibade, A.C. (1987) Some Metallogenic features of the Nigerian Basement. Journal of African Earth Sciences, 6, 655-664. http://dx.doi.org/10.1016/0899-5362(87)90004-2

[6] Tuttle, O. F. and Bowen, N. L. (1958) The origin of Granite in the Light of Expiremental Studies in the system $\mathrm{NaAl} \mathrm{Si}_{3} \mathrm{O}_{8^{-}}-\mathrm{KAl} \mathrm{Si}_{3} \mathrm{O}_{8^{-}}$ $\mathrm{SiO}_{2}$

$\mathrm{H}_{2} \mathrm{O}$. Geol. Soc. America Mem $74 \mathrm{~s}$

[7] Falconer, J. D. (1911) The geology and geography of Northern Nigeria, Macmillan London, 135pp.

[8] Frost, B. R. \& Lindsley, D. H. (1991) The Occurrence of Fe-Ti Oxides in Igneous Rocks.

[9] John, B. E. \& Wooden, J. (1990) Petrology and Geochemistry of the Metaluminous to Peraluminous Chemehuevi Mountains Plutonic Suites, Southeastern Carlifornia.

[10] Barbarin, B. (1990) Granitoids: Main Petrogenetic Classification in relation to Origin and Tectonic Setting. Geological Journal 25, 227-238 http://dx.doi.org/10.1002/gj.3350250306

[11] Kankara, I. A. (2014) Geochemical Characterization of Rocks in Funtua Sheet 78 North-East, Scale 1:50,000 Northwestern Nigeria. An Unpublished PhD Thesis, Department of Geology, Federal University of Technology, Minna-Nigeria

\section{Brief Biography of the Author}

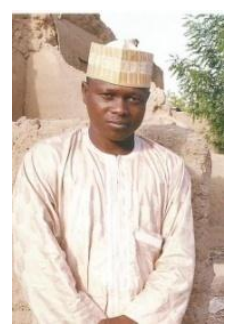

Dr. Aliyu Ibrahim Kankara was born at Kankara in Katsina State Nigeria on Friday $20^{\text {th }}$ December, 1968. He was educated at Ahmadu Bello University Zaria, Nigeria and Bayero University Kano-Nigeria where he obtained BSc. Geology and MSc. Land Resources Development in 1994 and 2001 respectively. In 2014, he earned $\mathrm{PhD}$ degree in Geology with specialization in Mineral Exploration from Federal University of Technology

Minna Nigeria. Dr. Aliyu worked as Unit Head, Rural Water Supply In the Works Department of Kankara Local Government, Katsina State from 1990 to 1996. He Taught Chemistry and Physics as a classroom teacher at the Government Girls Senior Science Secondary School (GGSSSS) Sandamu Katsina State, under State Ministry of Education in 1996, before moving to the prestigious Kaduna Polytechnic as a LECTURER in the College of Engineering, Department of Mineral Resources Processing, where he taught all geology-based Disciplines, between 1996 to 1999. Between 1999 to 2001, Aliyu worked as
PROJECT GEOLOGIST at the CGC Nigeria Limited Katsina and Sokoto offices. He was back to classroom as Chemistry and Geography Master at Government Day Secondary School Dandume and Government Girls Secondary School Daudawa both in Katsina State, between 2001 to 2006. He was temporarily seconded to Basic Agriculture and Soil Science Training College, Daudawa, Katsina State (Part Time) between 2004 to 2005.

He was a LECTURER II at the Dept. of Geography, Umaru Musa Yar'adua University, Katsina, between 2006 to 2012. He is currently a SENIOR LECTURER, Department of Geography and Regional Planning, Federal University Dutsinma, Nigeria. He has published about 23 articles in reputable journals, some of which are listed below:

1. Kankara, I. A. and Farouk, H A. (2015) Provisional Dating of Metasedimentary Rocks in South Katsina State, Northwestern Nigeria: Studies in Proterozoic Crustal Evolution. Journal of Physical Sciences and Environmental Studies. Vol. 1 (4), pp 55-61, October 2015 ISSN 2467-8775. Review http;// pearlresearchjournals.org/journals/index.html.

2.Kankara, I. A., Darma, M. R and Abdullahi, S. (2016) Effect of Artisanal Gold Mining at Maiwayo Environ, Northern Nigeria: Implication for Environmental Risk. International Journal of Advanced Studies in Ecology, Development and Sustainability. ISSN- Hard Prints: 23544252. Online: 2354-4260. Vol. 4 No. 1 April 2016.

3. Darma, M. R., Kankara, I. A., Adamu, A. Gambo, G. and Gafia B. A. (2016) Perception of Safety and Security of Economy of Africa: Shortfall in Solid Mineral Exploitation in Contemporary Nigeria. Social Science Journal of Policy Review and Development Strategies. Hard Prints: 2488-9636. Online: 2488-9628. Vol. 2 No. 1 April 2016.

4. Kankara, I. A., Bazza, L. M. and Garba, I. (2016). Examining Groudwater Pollution in Central Katsina City. A paper published in the Journal of Hydraulic Engineering 1 (2016) doi $10.1726523 \quad 32-82$ 15/2016.01.003. ISSN: 2332-8215. Website: http://www.davidpublishers.org/Home/Journal/JHE. Vol. 1 No. 1, Jan.March 2016 (Serial Number 2) He has also published three (3) books:

1. The Geology, Geography and Mineral Resources of Katsina State, Nigeria (Katsina, Katsina: Labson Production Kaduna, 2014)

2. Dictionary of Earth Sciences (Katsina, Katsina: Naja'atu Publishers, Katsina, 2015)

Dr. Kankara has obtained many awards, such as:

1. Science/Geography Tutor, Refresher Courses, Funtua, Katsina State, 2003-2005

2. Participant, WAEC and NECO marking, 2006 to 2008.

5. INEC Ad hoc Staff (Returning/Collation officer) for 2011 General Elections.

6. Guest of the Week, Science Program, Bauchi State Television, 19/2/2013

7. Guest Speaker, $12^{\text {th }}$ Graduation and Annual Lecture of Katsina Vocational Centre, 30/8/2012

8. INEC Ad hoc Staff (Returning/Collation officer) for 2015 General Elections.

9. Chairman, Association for Humanitarian Services and Environmental Protection, Katsina State (AHUSEP)

10. Chairman, Electoral Committee of the Election of Leaders Association of Nigerian Authors (ANA) Katsina State Chapter, 2016. Dr. Kankara is also the author of Author, Shata Ikon Allah, and Mahadi Mai Dogon Zamani: Shata Da Kundin Wakokinsa. Biographies of Late Hausa Music Icon, Dr. Mamman Shata Katsina 2006 and 2013, and 30 other books written in native Hausa and English language. 
Appendix 1: Chemical (Weight Percent) Composition of Zungeru Granites

\begin{tabular}{ccccccccccc}
\hline Sample No. & F1 & F3 & F2 & F65 & F134 & F126 & F125 & F35 & F109 & F136 \\
\hline $\mathrm{Si}_{2}$ & 71.45 & 71.86 & 71.62 & 72.8 & 72.8 & 71.6 & 73.4 & 70.3 & 71.8 & 73.0 \\
& & & & & & & & & & \\
$\mathrm{Al}_{2} \mathrm{O}_{3}$ & 14.66 & 14.77 & 14.40 & 13.6 & 12.2 & 14.8 & 13.4 & 15.3 & 14.2 & 13.0 \\
$\mathrm{Ca} 0$ & 1.82 & 1.55 & 1.33 & 1.45 & 1.78 & 1.61 & 0.92 & 2.3 & 1.8 & 1.9 \\
$\mathrm{~K}_{2} 0$ & 3.55 & 3.96 & 3.90 & 3.24 & 4.08 & 2.61 & 3.4 & 3.82 & 4.08 & 3.61 \\
$\mathrm{Na}_{2} 0$ & 2.41 & 2.94 & 3.07 & 3.42 & 2.81 & 3.61 & 2.0 & 2.38 & 2.71 & 2.92 \\
$\mathrm{Mg}_{0}$ & 0.37 & 0.42 & 0.34 & 0.6 & 0.6 & 0.8 & 0.21 & 0.75 & 0.76 & 0.22 \\
$\mathrm{P}_{2} 0_{5}$ & 0.08 & 0.15 & 0.12 & 0.02 & 0.09 & 0.21 & 0.32 & 0.16 & 0.19 & 0.06 \\
$\mathrm{Fe}_{2} \mathrm{O}_{3}$ & 1.06 & 1.86 & 1.69 & 1.08 & 2.03 & 1.97 & 2.55 & 1.65 & 1.46 & 1.42 \\
$\mathrm{Ti}_{2}$ & 0.25 & 0.22 & 0.20 & 0.51 & 0.28 & 0.31 & 0.24 & 0.20 & 0.32 & 0.29 \\
$\mathrm{Mn0}$ & 0.052 & 0.028 & 0.031 & 0.61 & 0.79 & 0.72 & 0.011 & 0.086 & 0.016 & 0.081 \\
$\mathrm{LOI}$ & 1.58 & 1.52 & 1.20 & 1.88 & 1.44 & 0.48 & 1.33 & 0.98 & 1.23 & 1.9 \\
$\mathrm{Total}$ & $\mathbf{9 7 . 2 8}$ & $\mathbf{9 9 . 2 8}$ & $\mathbf{9 7 . 9 0}$ & $\mathbf{9 9 . 2 1}$ & $\mathbf{9 8 . 9 0}$ & $\mathbf{9 8 . 7 2}$ & $\mathbf{9 7 . 7 9}$ & $\mathbf{9 7 . 9 3}$ & $\mathbf{9 8 . 5 7}$ & $\mathbf{9 8 . 4 0}$ \\
\hline
\end{tabular}

Appendix 2: Trace Elements Composition (ppm) of Zungeru Granites

\begin{tabular}{ccccccccccc}
\hline Sample No. & F1 & F3 & F2 & F65 & F134 & F126 & F125 & F35 & F109 & F136 \\
\hline $\mathrm{Cu}$ & 22.6 & 7.5 & 18.5 & 10.5 & 11.0 & 10.0 & 12.2 & 13.8 & 15.7 & 15.0 \\
$\mathrm{Co}$ & 58.0 & 11.7 & 52.6 & 48.0 & 48.6 & 41.8 & 42.2 & 51.7 & 58.7 & 52.6 \\
$\mathrm{Ni}$ & 12.7 & 7.8 & 12.4 & 8.0 & 8.0 & 7.5 & 7.5 & 12.6 & 12.7 & 8.0 \\
$\mathrm{Zn}$ & 44.7 & 38.0 & 40.0 & 39.5 & 41.0 & 41.8 & 43.6 & 43.6 & 44.8 & 44.7 \\
$\mathrm{Rb}$ & 105.0 & 90.0 & 116.6 & 98.8 & 98.3 & 102.3 & 102.1 & 112.2 & 116.7 & 100.0 \\
$\mathrm{Cr}$ & 12.8 & 15.0 & 12.2 & 15.9 & 13.2 & 14.7 & 13.5 & 14.6 & 11.0 & 12.8 \\
$\mathrm{~Pb}$ & 25.0 & 26.5 & 29.0 & 24.0 & 24.5 & 26.6 & 27.8 & 27.7 & 29.5 & 26.0 \\
$\mathrm{Sr}$ & 217.0 & 317.0 & 270.7 & 318.0 & 326.0 & 310.0 & 211.8 & 250.5 & 261.5 & 296.7 \\
$\mathrm{Zr}$ & 188.8 & 178.5 & 222.0 & 192.0 & 196.7 & 210.0 & 179.7 & 182.9 & 186.8 & 200.0 \\
$\mathrm{Ba}$ & $1,177.4$ & $1,321.5$ & 838.2 & 902.3 & 960.2 & 992.6 & 806.9 & $1,250.0$ & 1320.5 & $1,182.5$ \\
$\mathrm{La}$ & 36.8 & 27.3 & 27.0 & 28.9 & 28.2 & 28.0 & 30.6 & 32.8 & 31.7 & 35.6 \\
\hline
\end{tabular}

